\title{
A Bibliometric Analysis of Soil and Water Conservation in the Loess Tableland-Gully Region of China
}

\author{
Yaping Wang ${ }^{1}$, Wenzhao Liu ${ }^{1, *}$, Gang Li ${ }^{1}$, Weiming Yan ${ }^{1}\left(\mathbb{D}\right.$ and Guangyao Gao ${ }^{2}$ \\ 1 State Key Laboratory of Soil Erosion and Dryland Farming on the Loess Plateau, Institute of Soil and Water \\ Conservation, Northwest A\&F University, 26 Xinong Road, Yangling 712100, China; \\ wangyaping0410@163.com (Y.W.); sddplg620@163.com (G.L.); yanweiming0110@126.com (W.Y.) \\ 2 State Key Laboratory of Urban and Regional Ecology, Research Center for Eco-Environmental Sciences, \\ Chinese Academy of Science, Beijing 100085, China; gygao@rcees.ac.cn \\ * Correspondence: wzliu@ms.iswc.ac.cn; Tel.: +86-29-8701-2307; Fax: +86-29-8701-2210
}

Received: 2 November 2018; Accepted: 17 December 2018; Published: 22 December 2018

check for updates

\begin{abstract}
The tableland-gully region is one of the main topographic-ecological units in the Chinese Loess Plateau (CLP), and the soil in this region suffers from serious water erosion. In recent years, much work has been conducted to control soil erosion in this area. This paper summarized the development of soil and water conservation researches in the CLP from the bibliometric perspective based on the Science Citation Index (SCI) and Chinese National Knowledge Infrastructure (CNKI) databases. The quantity of SCI literatures has increased rapidly since 2007, with an average annual growth rate of $21.4 \%$, and the quantity of CNKI literatures in the last decade accounted for $62 \%$ of the past 30 years. The development trends showed that early SCI research was related to loess geology in the context of ecological remediation, while the CNKI literature focused on agricultural production under comprehensive management. Over time, the research themes of the two databases gradually became unified, i.e., the management of sloping farmland and the improvement of agricultural productivity. Subsequently, the themes gradually extended to the disposition of comprehensive control measures for soil erosion and the environmental effect of agro-fruit ecosystems. The highly cited papers mainly focused on soil reservoir reconstruction, soil erosion factors, and environmental effects of vegetation restoration. Two aspects need further study, including (i) the effect of soil erosion control under different ecological remediation patterns; and, (ii) the ecosystem maintenance mechanism and regulation approaches that are based on the sustainable utilization of soil and water resources in the tableland-gully region of the Loess Plateau.
\end{abstract}

Keywords: bibliometric analysis; soil erosion; soil and water conservation; the Chinese Loess Plateau

\section{Introduction}

Soil erosion is an important land degradation process worldwide, and it has already greatly affected soil productivity and sustainable development [1]. The global soil erosion area is approximately $1.643 \times 10^{7} \mathrm{~km}^{2}$, which accounts for $10.95 \%$ of the total global land area and $84 \%$ of the total degraded area [2,3]. Healthy soil is essential to achieving many of the sustainable development of agriculture [4]. Some scholars tried to solve the problem of sediments from agricultural areas reaching the channel and reservoirs by conducting studies on hillslope-channel connectivity and catchment connectivity $[5,6]$. Studies of soil erosion in European vineyards have been carried out for many years [7], in vineyards of Eastern Spain, for example, $30 \%$ of the rainfall was transformed into superficial runoff, and the soil erosion rates reached $4.1 \mathrm{Mg} \mathrm{ha}^{-1} \mathrm{~h}^{-1}$ [8]. Severe soil erosion leads to 
nutrient loss $[9,10]$ and decreased land productivity [11,12]. Therefore, soil erosion is a severe threat to the sustainable development of resources and the environment worldwide [13].

The Loess Plateau, located in northern China, is the birthplace of the Chinese farming culture, and it is one of the most serious areas of soil and water loss in the world [14]; specifically, the soil erosion rate is greater than $3600 \mathrm{t} /\left(\mathrm{km}^{2} \cdot \mathrm{a}\right)$ in areas with a slope gradient over $8^{\circ}$ [15], causing riverbed uplift and flooding [16]. The prevention of soil erosion and improvement to the ecological environment are major environmental problems of universal concern $[15,17]$ as well as important measures that can be used to practice China's ecological civilization of "Beautiful scenery is the gold and silver mines".

The tableland-gully region is one of the main topographic-ecological units in the Chinese Loess Plateau (CLP). Due to its flat topography, open land, and fertile soil, the CLP has developed into an important provincial grain production base and a world-famous high-quality apple production area. However, the CLP has also suffered severe soil erosion, with a soil erosion rate of $2920.5 \mathrm{t} /\left(\mathrm{km}^{2} \cdot \mathrm{a}\right)$ from 1998-2007; furthermore, this value is higher than $5000 \mathrm{t} /\left(\mathrm{km}^{2} \cdot \mathrm{a}\right)$ in some areas [18], which has seriously affected the sustainable development of the regional resources and environment $[17,19]$. Accordingly, much work has been done on soil and water conservation through different scales and methods [20-23], and these efforts have achieved remarkable results; thus, the quantity of the literatures is increasing.

Bibliometric analysis is a quantitative analysis method that is based on mathematical statistics [24], and the method uses the literature to evaluate the development of a subject field [25]. Currently, many scholars have explored the frontiers and hotspots of subject-specific research using this method [26-28]. Studies on soil and water conservation in the tableland-gully region of the CLP have been carried out for many years, which produced a large number of academic publications. Therefore, it is necessary to conduct a comprehensive review using the bibliometric method to analyze the history, summarize the existing experience, and identify the problems and directions that require further study.

The objectives of this research are as follows: (i) explore the characteristics of soil and water conservation research at different stages; (ii) reveal the focal and frontier issues in this field; and, (iii) propose relevant suggestions to promote vegetation construction, soil erosion control, and sustainable development of ecosystems in the tableland-gully region of the CLP.

\section{Materials and Methods}

\subsection{Data Compilation}

Based on the Science Citation Index (SCI) published by the American Institute of Scientific Information and Chinese National Knowledge Infrastructure (CNKI) databases, all of the available peer-reviewed literature published from 1987-2016 and related to soil and water conservation were collected. First, the subject words were used to retrieve the literature focused on the tableland-gully region of the CLP. Second, relevant subject words were selected according to the research direction, which were combined by using the operators "or" and " $\&$ ", and then the relevant literature on soil and water conservation was searched. The literature types were articles, and the database update time was set to 30 December 2016; the data were exported in accordance with the provisions of the CiteSpace software [24] format.

The retrieval results were manually searched and screened in advance to omit repetition. From 1987 to 2016, a total of 2753 SCI and 1294 CNKI studies about soil and water conservation in the tableland-gully region of the CLP were obtained. Eventually, visual analysis was carried out using CiteSpace tools.

\subsection{Methods}

CiteSpace software was used in this study (5.0.R4 SE); CiteSpace is a Java application for analyzing and visualizing a co-citation network [29]. CiteSpace can be used to quantitatively analyze the literature in specific fields and explore the key paths and development frontiers during the evolution of a subject field through a series of visual maps [30,31]. 
In this study, the keyword node was selected for the operation of the software. Keywords are highly generalized and refined terms that reflect the core of an article, and therefore, the frequency of keyword usage can reflect the main research field to a certain extent. In the co-occurrence map, the size of each ring represents the occurrence frequency of each keyword; the larger the ring is, the more frequently the keyword occurs. The thickness of the connection line between keywords indicates the intensity of co-occurrence of a keyword, and adjacent keywords indicate that they appear in the same article [32]. The color and thickness of the node ring indicate the time when the keywords appear. The thicker the purple ring outside the annual ring, the higher the centrality of the keyword, indicating that the node is located close to the center of the keyword network [29]. The time range of this software analysis is 1987-2016.

\section{Results and Discussion}

\subsection{Temporal Change in the Literature Quantity}

The changes in the quantity of literature can be used to analyze the development stage and growth trend of a particular discipline. First, we analyzed the temporal change in the literature quantity over the past 30 years (Figure 1). It is clear from Figure 1 that, in the early stages of research, the amount of total literatures changed little, and the annual output and annual increment of the literature from 1987-1996 were 14.4 and 3.6, respectively, which were low. Subsequently, the number of studies began to increase, the annual output from 1997-2006 was 77, and the annual number increased by 12, showing an upward trend in both output and annual increment. In the later period, the number of studies began to increase substantially, and the output and annual increment from 2007-2016 reached 313.3 and 42, respectively, which were the highest throughout the study period. In addition, the quantity of SCI literatures increased slowly in the early stage and began to increase rapidly in 2007, with an average annual growth rate of $21.4 \%$. A total of 1294 articles were published in CNKI, and the quantity of CNKI literatures in 1987-1996, 1997-2006, and 2007-2016 accounted for $8 \%, 30.4 \%$, and $61.6 \%$ of the past 30 years, respectively. Although the amount of CNKI literatures has not changed, it has maintained a high level, indicating that the research on soil and water conservation in the tableland-gully region has not slowed, but the detail and diversity of the research have increased. Based on these patterns, this study can be roughly divided into three stages for analysis and description: 1987-1996, 1997-2006, and 2007-2016.

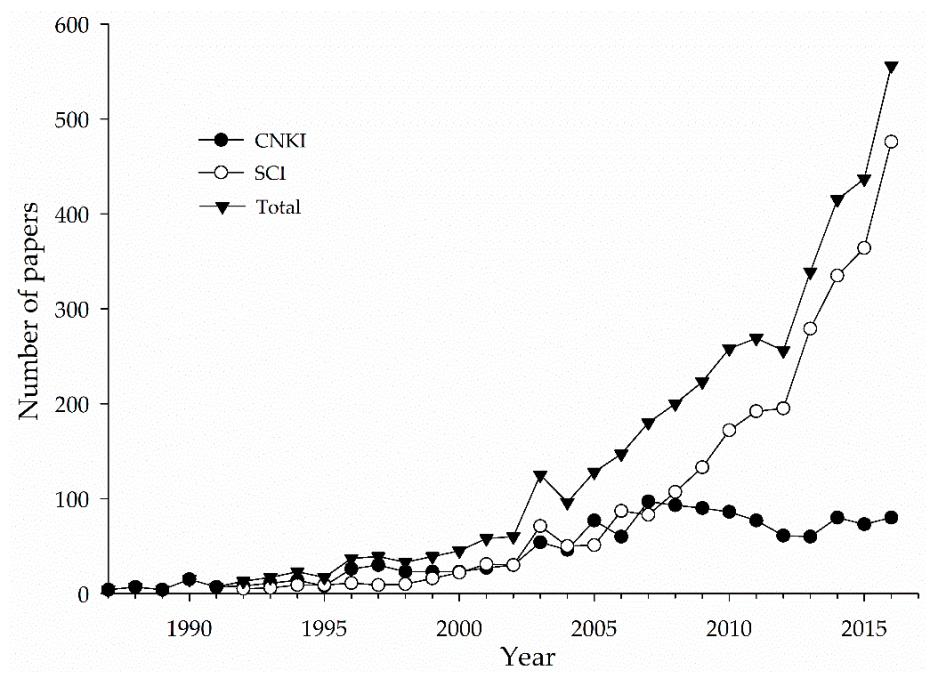

Figure 1. Annual quantity of literatures on soil and water conservation from 1987 to 2016.

Overall, due to the implementation of the Seventh Five-Year Plan (1986-1990), which was a project of China's national economic and social development from 1986 to 1990, the government has paid more attention to soil and water conservation in the CLP. In addition, the advances in science and 
technology and the promotion of social development have also increased the number of research papers on soil erosion control in the tableland-gully region of the CLP.

\subsection{Research Hotspot}

In this paper, CiteSpace software was used to analyze the bibliometric SCI literature network, and the keywords that occurred at high frequencies based on the statistical analysis by CiteSpace software are regarded as the annual research hotspots. The research at each stage is as follows:

3.2.1. Increasing Grain Yield and Readjusting the Structure of Land Use; however, SCI Literature Focused Primarily on Loess Geological Characteristics in the Context of Ecological Remediation (1987-1996)

In the early stage, there were differences in the research hotspots between SCI and CNKI literature, but both were carried out under the background of comprehensive regional management. The large rings are paleoclimate, soil, and stratigraphy (Figure 2), and they are intertwined and linked to each other, which indicates that the loess geological characteristics in the context of ecological remediation have been a hotspot. For instance, the difference in paleosol formation is mainly reflected in the concentration and variation in the particle size of magnetic minerals [33], climate is the predominant factor that controls the enhancement of pedogenic susceptibility in loess soil [34]. By studying the paleosols, phytolith assemblage, and organic carbon isotopes, some scholars found that grassland is the main vegetation in the CLP during the Holocene [35]. The high-frequency keywords of CNKI literature indicate that related research has focused on the improvement to land productivity under the background of small watershed management (Table 1), which mainly popularizes dryland farming technology and optimizes the modes of fertilization and cultivation to strengthen the farmland capital construction and increase the unit area yield [36,37]. In addition, soil erosion prediction models and remediation measures were also hotspots during this stage [38], which laid a foundation for soil and water conservation research. The related research classified soil erosion grades by combining slope, micro-geomorphic and soil erosion type factors [39,40], and evaluated the soil erosion risk that is posed by these different factors [41,42].

Table 1. Annual distribution of the main research topics of Chinese National Knowledge Infrastructure (CNKI) literature from 1987-1996.

\begin{tabular}{ccc}
\hline Year & Quantity of Literatures & Top 5 Keywords \\
\hline 1987 & 4 & Soil loss, Rainfall intensity, Storm runoff, Gully erosion, Control area \\
\hline 1988 & 7 & $\begin{array}{c}\text { Comprehensive control, Small watershed management, Crop yield, } \\
\text { Soil erosion, Orchard }\end{array}$ \\
\hline 1989 & 4 & $\begin{array}{c}\text { Sediment discharge, Soil moisture, Erosion, Sediment reduction } \\
\text { efficiency, Soil erosion modulus }\end{array}$ \\
\hline 1990 & 15 & $\begin{array}{c}\text { Small watershed management, Biological measures, Soil and water } \\
\text { conservation, Rainfall characteristics, Land productivity }\end{array}$ \\
\hline 1991 & 7 & $\begin{array}{c}\text { Ecological environment, Watershed management, Control area, } \\
\text { Construction project, Soil and water conservation forest }\end{array}$ \\
\hline 1993 & 11 & $\begin{array}{c}\text { Ecological-economic system, Soil and water conservation, Crop } \\
\text { breeding, Watershed, Control area }\end{array}$ \\
\hline 1994 & 14 & $\begin{array}{c}\text { Soil and water conservation, Gully slope development, Soil erosion, } \\
\text { Robinia pseudoacacia forest, Vegetation construction }\end{array}$ \\
\hline 1995 & 8 & $\begin{array}{c}\text { Shelter forest system, Yield, Agro-ecosystem, Comprehensive } \\
\text { control, Straw mulching }\end{array}$ \\
\hline 1996 & 26 & $\begin{array}{c}\text { Land resource, Fertilizer, Ecological environment, Forestry, } \\
\text { Exploitation and utilization }\end{array}$ \\
\hline
\end{tabular}




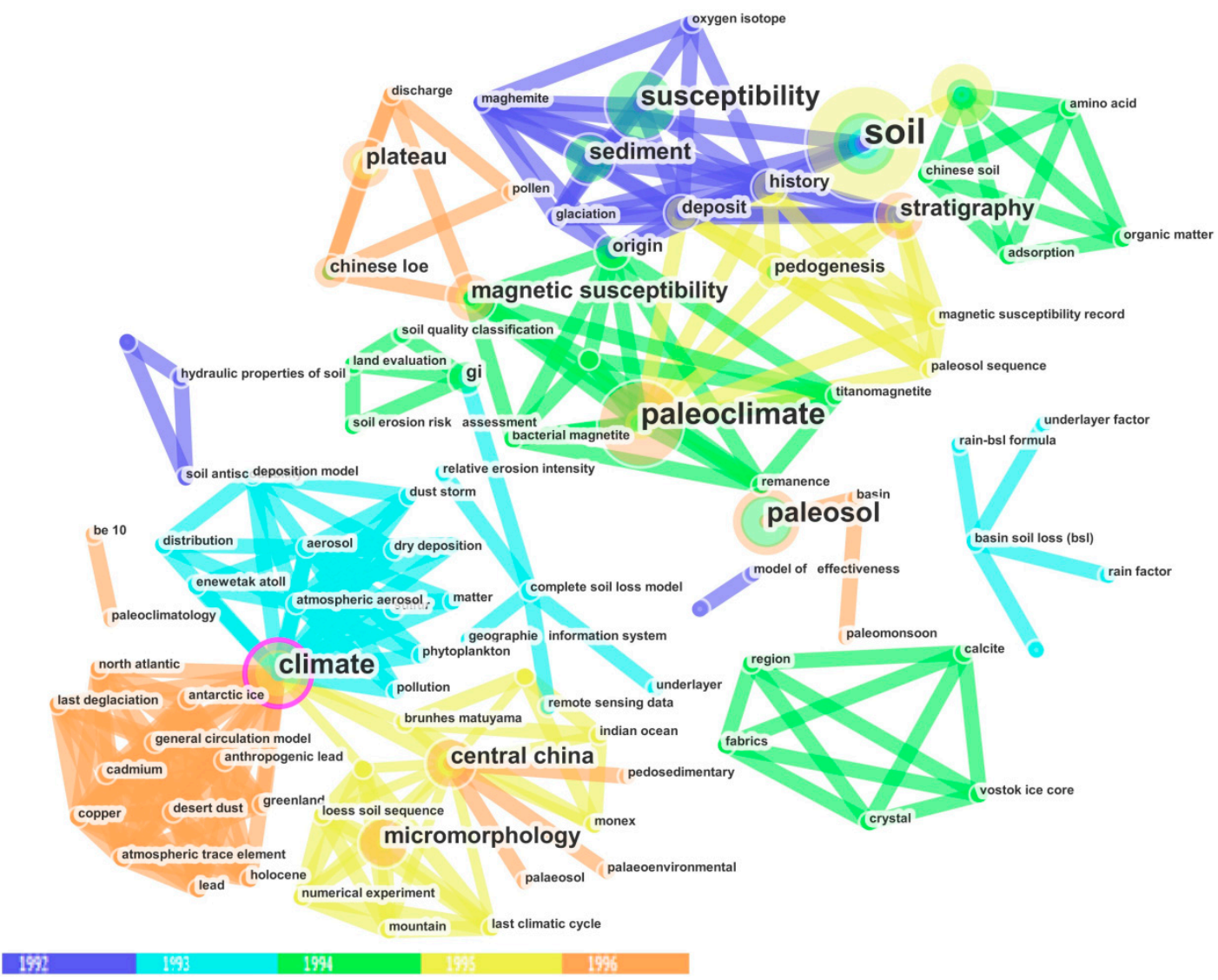

Figure 2. The bibliometric network map of keywords based on Science Citation Index (SCI) literature from 1992-1996.

Overall, soil and water conservation research had only begun to boom at this stage, so only some a few scholars identified the relevant measures. Although comprehensive management of small watersheds is complex [43], it is indeed an effective measure for the rational use of land and control of sediment, and it has been proven to be effective [44].

3.2.2. Taking Small Watersheds as a Unit, Managing the Tableland-Gully Region while Primarily Controlling Ditches and Configuring Soil Erosion Prevention and Control Measures (1997-2006)

When compared with the network map of the previous stage, the number of nodes and the frequency of the keywords greatly increased during this period (Figure 3), and the hotspots were gradually transformed into the comprehensive control of soil erosion (Table 2). Figure 3 also shows that climate, erosion, and paleosol have large rings, which indicates that these keywords have high frequencies. The keywords "climate", "plateau", and "erosion" have a purple ring around them, indicating that these keywords were located near the center of the bibliometric network map. In addition, all of the keywords are fused with each other and have strong connectivity. The following studies were carried out during the period: (i) Effects of climate and vegetation change on regional hydrology, soil erosion, and crop yield $[45,46]$. By establishing a vegetation coverage and soil erosion model [47], it was found that soil erosion that is caused by vegetation destruction was the key factor that accelerated land degradation [3]. (ii) The effects of land use and management on land degradation and soil quality [48], experimental demonstrative research on crop yield, and the protection of soil ecological function [49], such as the exploration of check-dam systems [50] and the effects of straw mulching and organic matter application on moisture conservation and yield increases [51,52]. (iii) Improvement of comprehensive soil erosion control measures from the socioeconomics viewpoint, which includes the optimization of land use structure. Some experts noted that forest and grass areas 
should be given equal attention during vegetation restoration [53]. In addition, the comprehensive management of soil erosion must be combined with the rich demands of farmers, i.e., on the basis of improving land productivity, maintaining regional grain security, and promoting the comprehensive management of gully slopes [16].

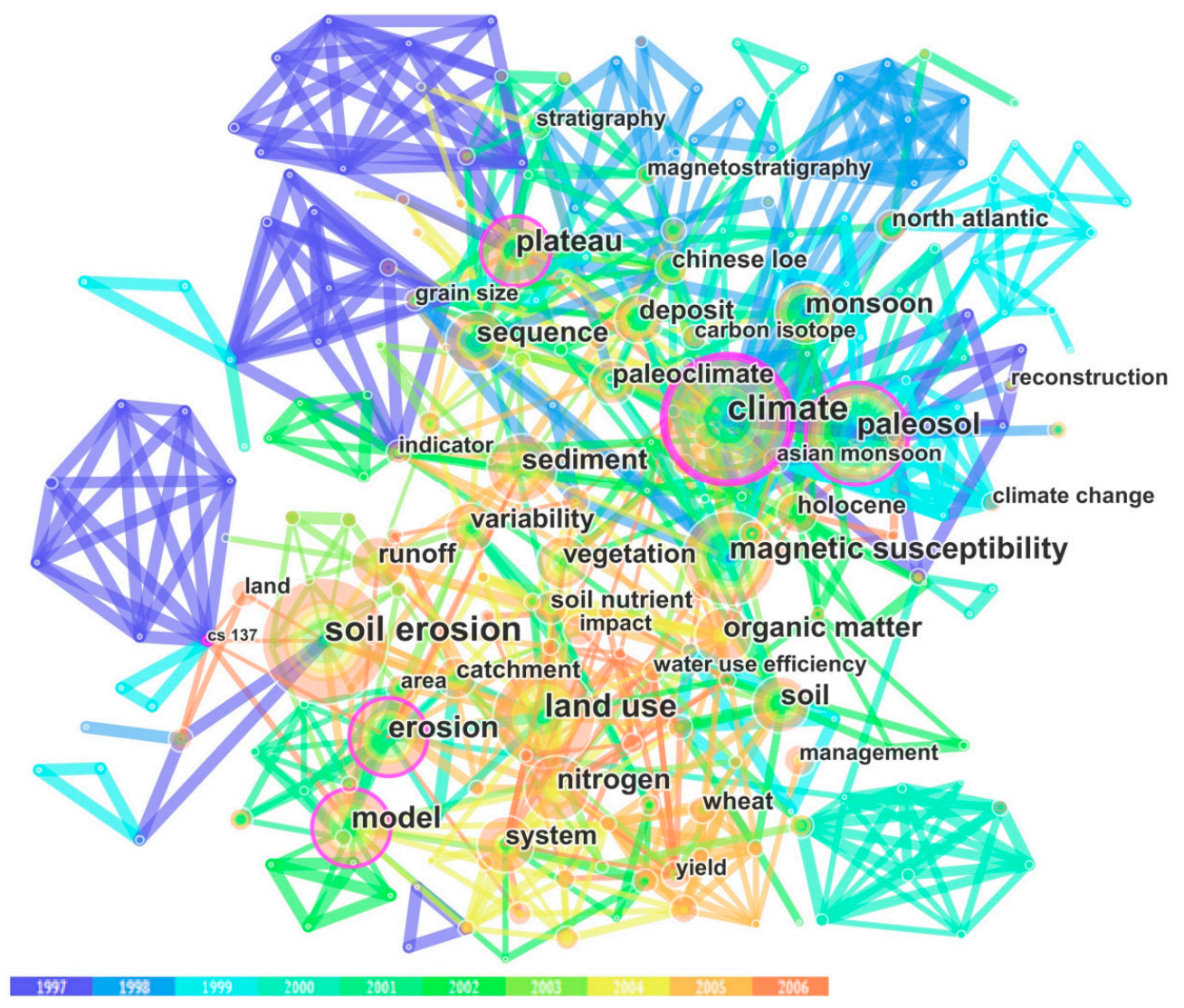

Figure 3. The bibliometric network map of keywords based on SCI literature from 1997-2006.

Table 2. Annual distribution of the main research topics of CNKI literature from 1997-2006.

\begin{tabular}{|c|c|c|}
\hline Year & Quantity of Literatures & Top 5 Keywords \\
\hline 1997 & 30 & $\begin{array}{c}\text { Maize, Control area, Soil and water conservation measure, Remote } \\
\text { sensing, Soil erosion modulus }\end{array}$ \\
\hline 1998 & 23 & $\begin{array}{l}\text { Runoff, Shelter forest construction, Biological measures, Tillage, } \\
\text { Vegetation construction, Winter wheat }\end{array}$ \\
\hline 1999 & 23 & Sloping land, Watershed, Sediment yield, Control area, Winter wheat \\
\hline 2000 & 23 & $\begin{array}{c}\text { Soil erosion, Soil structure, Land degradation, Afforestation, } \\
\text { Comprehensive control }\end{array}$ \\
\hline 2001 & 27 & $\begin{array}{l}\text { Soil and water conservation, Comprehensive control, Wheat, Apple } \\
\text { orchard, Small watershed }\end{array}$ \\
\hline 2002 & 30 & $\begin{array}{l}\text { Winter wheat, Soil moisture, Sloping land, Grain for Green, } \\
\text { Afforestation }\end{array}$ \\
\hline 2003 & 54 & $\begin{array}{c}\text { Small watershed, Soil erosion, Soil moisture, Ecological environment, } \\
\text { Soil nutrient }\end{array}$ \\
\hline 2004 & 46 & $\begin{array}{l}\text { Environment, Ecological construction, Afforestation, Soil organic } \\
\text { carbon, Soil erosion, Grain for Green }\end{array}$ \\
\hline 2005 & 77 & $\begin{array}{l}\text { Soil and water conservation, Winter wheat, Small watershed, Dry soil } \\
\text { layer, Nitrogen fertilizer }\end{array}$ \\
\hline 2006 & 60 & $\begin{array}{c}\text { Grassland, Soil and water conservation, Robinia pseudoacacia forest, } \\
\text { Rainwater resources, Sustainable development }\end{array}$ \\
\hline
\end{tabular}


Above all, in the field of soil and water conservation research, comprehensive management of small watersheds became a research hotspot during this period, and this field of study has been widely evaluated by researchers and developed rapidly. The comprehensive management of soil and water loss refers to the activities of adjusting the structure of land use, rationally allocating engineering, plants, and tillage measures of soil and water conservation on the basis of unified planning, so as to realize the protection, improvement, and rational utilization of regional water and soil resources [54,55]. The "Grain for Green" project and ecological restoration are complementary to each other and combined with the comprehensive management of small watersheds, thus making the management of soil and water loss in the Loess Plateau more scientific and ecological [56,57]. Furthermore, the research at this stage also focused on the combination of field experiments and models [58], the influence factors were gradually refined, and the research mechanisms were continuously deepened [59].

3.2.3. The Two-Element Agricultural Model of Grain and Fruit was Popularized, and the Ecological Construction and Environmental Effects were Gradually Emphasized (2007-2016)

The research topics of the two kinds of literature were more concentrated at this stage. That is, with the progression of the research, the research hotspots of the CNKI and SCI literature gradually became focused, and the research content gradually unified. Figure 4 shows that soil erosion is locked in the center of the rings and it is blended with the ecosystem, vegetation, climate, organic matter, and catchment keywords. When compared with the previous two stages, there are many nodes from 2007-2016 that are highly concentrated, and the cross-combination among various research fields has been enhanced significantly. The frequency of the keywords "land use", "vegetation", and "soil erosion" grew rapidly in these years, and the frequency keyword of land use, associated with soil moisture and spatial variability, etc., which suggests that research on the ecological benefits and functional evaluation under different management modes is expanding. Additionally, there is also a high frequency of soil erosion in the CNKI literature (Table 3). With the adjustment to the land use structure, the two-element agricultural model of grain and fruit has become an important ecological remediation model in the tableland-gully region of the CLP [60], and research on the structures and function of ecosystems has gradually strengthened [61,62].

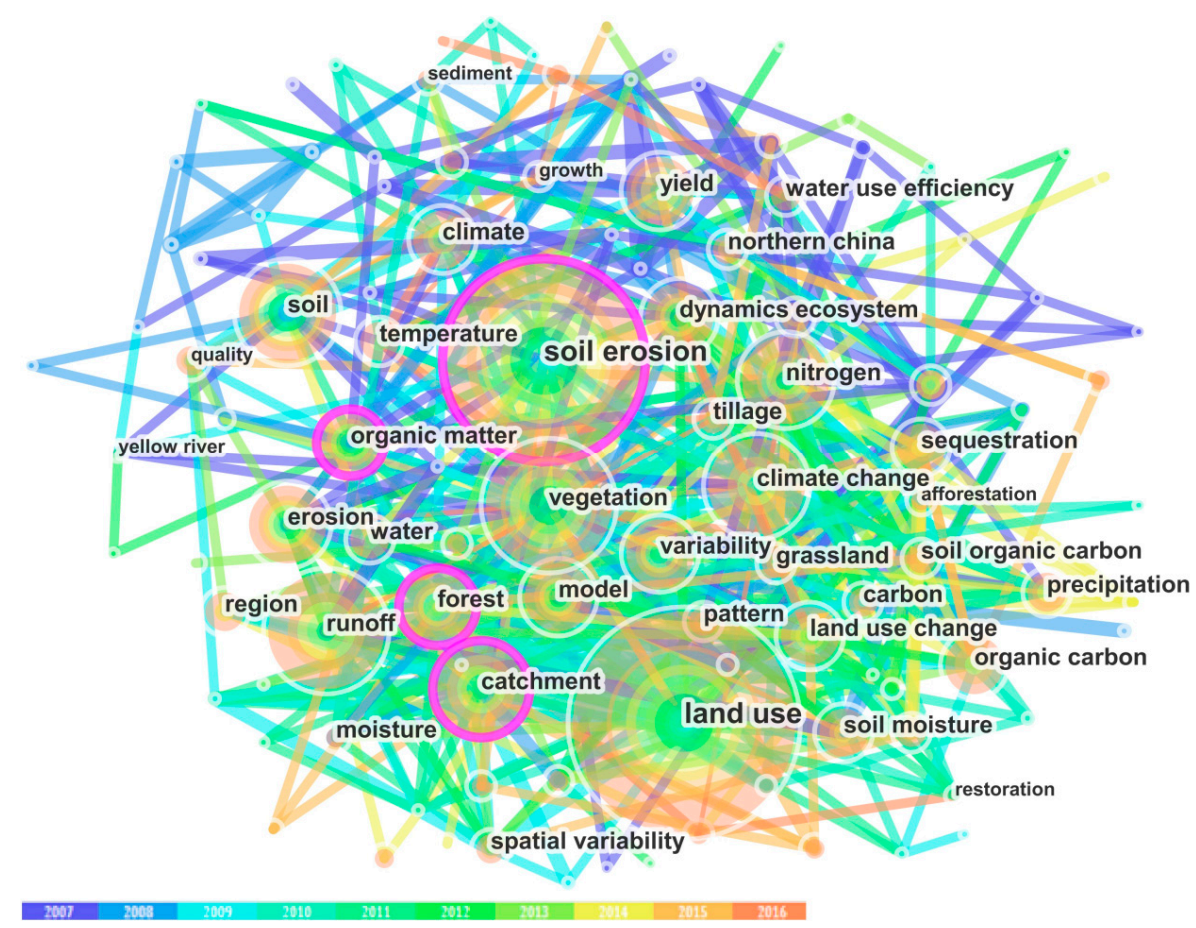

Figure 4. The bibliometric network map of keywords based on SCI literature from 2007-2016. 
Table 3. Annual distribution of the main research topics of the CNKI literature from 2007-2016.

\begin{tabular}{|c|c|c|}
\hline Year & Quantity of Literatures & Top 5 Keywords \\
\hline 2007 & 97 & $\begin{array}{l}\text { Winter wheat, Soil erosion, Soil moisture, Soil and water conservation, Soil and } \\
\text { water loss }\end{array}$ \\
\hline 2008 & 93 & $\begin{array}{l}\text { Soil and water conservation, Small watershed, Ecological environment, Crop yield, } \\
\text { Organic carbon }\end{array}$ \\
\hline 2009 & 90 & $\begin{array}{l}\text { Soil and water conservation, Soil moisture, Climate change, Winter wheat, } \\
\text { Headward erosion }\end{array}$ \\
\hline 2010 & 86 & Soil moisture, Land use, Soil erosion, Small watershed, Crop yield \\
\hline 2011 & 77 & Land use, Soil erosion, Soil moisture, Soil and water conservation, Crop yield \\
\hline 2012 & 61 & Soil moisture, Crop yield, Land use change, Soil respiration, Water use efficiency \\
\hline 2013 & 60 & Soil moisture, Vegetation coverage, Nitrogen fertilizer, Wheat, Soil erosion \\
\hline 2014 & 80 & $\begin{array}{c}\text { Soil and water conservation, Robinia pseudoacacia forest, Soil nutrient, Grain for Green, } \\
\text { Soil respiration }\end{array}$ \\
\hline 2015 & 73 & Soil and water conservation, Ecological environment, Biomass, Runoff, Soil erosion \\
\hline 2016 & 80 & Apple orchard, Precipitation, Crop yield, Winter wheat, Benefit evaluation \\
\hline
\end{tabular}

The research at this stage is as follows: (i) ecological benefits of soil and water conservation measures, such as the "Grain for Green" project and check-dams. Check-dams are a soil and water conservation engineering facility built in a gully, which can be used to reduce sediment, control erosion, and build farmland [63]. Relevant studies include research on runoff and groundwater recharge processes [64] and the response of runoff and soil erosion to different precipitation patterns $[65,66]$. (ii) The regulation of water resources and the hydro-ecological processes of the CLP under different land use structures, e.g., shrub [23], orchard [67], and alfalfa grassland productivity dynamics and eco-environmental effects $[68,69]$. (iii) Effects of different land use types and management types on soil quality [70], including soil physical properties [71], total nitrogen, total phosphorus [72], and soil organic carbon [73]. In general, the eco-environmental effects and optimum utilization of soil and water resources under the regulation of land use structure have become hotspots.

\subsection{Highly Cited Papers}

Highly cited papers represent the development trend and important achievements of the research to a certain extent. The related studies were mainly in the following areas.

\subsubsection{Rebuilding "Soil Water Reservoir"}

It is necessary to maintain the sustainable development of agriculture in the CLP by fully collecting precipitation and combating drought. Therefore, the reconstruction of soil reservoirs is a research focus in this area, and some highly cited papers have been produced [74]. Due to the unique environmental conditions of dust-lowering accumulation and the continuous soil-forming process, the precipitation in the CLP infiltrates into an "underground reservoir". The conservation of "soil water reservoir" is a key issue for the integrated control of the ecological environment and the sustainable development of the CLP. Vegetation is the only active and sustained factor that can effectively intercept precipitation and create a "soil water reservoir", and the restoration and reconstruction of vegetation are irreplaceable for maintaining the "soil water reservoir" [75]. The implementation of the "28-character strategy" of land consolidation is an important measure for rebuilding the soil reservoir, effectively utilizing precipitation resources and restoring the eco-environment in the CLP [76].

3.3.2. Improving Farmland Water Use Efficiency, Increasing Yield per Unit Area and Promoting the Adjustment of Land Use Structure

The gully slope management of the "Grain for Green" project be effectively conducted only when the grain yield per unit area is increased in the tableland. However, the main reason for the low grain 
yield is the underutilization of rainfall in the tableland-gully region [77]; thus, there has been the rapid development of dry land water-saving agriculture, and reasonable water-saving measures have been proposed to improve agricultural production, which provides an important foundation for the comprehensive management of soil erosion in the tableland-gully region of the CLP $[48,78,79]$.

\subsubsection{Exploration of Soil Erosion Factors and Preventive Control Measures}

Based on the analysis of soil erosion factors in the CLP, climate change and vegetation cover are the main natural factors that affect the soil erosion rate in the Holocene, and human activities are responsible for the changes in soil erosion during the anthropogenic period [80]. In addition, soil erosion on sloping farmland is the main form of accelerated erosion and the main source of sediment input to the Yellow River. The key method of preventing soil erosion on sloping farmland is to weaken rainfall energy and improve soil erosion resistance $[16,40,44,81]$. Vegetation is of great significance in preventing soil erosion and intercepting precipitation, and a series of vegetation conservation measures have been implemented, such as the "Grain for Green" project, "controlling gully \& protecting tableland" policy, and check-dam construction, which have made substantial achievements [15].

\subsubsection{Environmental Effects of Vegetation Reconstruction}

Vegetation restoration is the main method that is used to solve soil erosion in the CLP. Increasing vegetation cover can effectively control soil and water losses, and it also strengthens the vertical water circulation process, weakens the hydrological cycle, and reduces the soil water content, which has been confirmed in related studies [82-84]. In addition, the discovery of a dry soil layer has also provoked interest in the environmental effects of vegetation reconstruction [85]. Although vegetation can effectively improve soil structure, change rainfall infiltration, and alter runoff formation [86], the improper selection of vegetation types and high-density management will aggravate the desiccation of deep soil $[87,88]$. Therefore, vegetation construction in the CLP should pay more attention to the relationship between the zonal distribution of vegetation and soil moisture to improve the utilization of rainwater resources and alleviate the soil desiccation [89].

\section{Several Aspects that Need to be Further Studied}

Soil erosion is a very comprehensive and complex process with temporal dynamics and spatial heterogeneity characteristics. Especially after the "Grain for Green" project, land use patterns have changed greatly and affected the climate and distribution of soil water in the CLP. Controlling soil erosion, protecting the ecological environment, and ensuring food security provide new opportunities and challenges for the study of soil erosion and ecological remediation. Based on a literature search and review, this study summarized the research characteristics of different stages as well as the research hotspots of the highly cited literature. In addition, combined with the information in Figures $2-4$ and the special natural geographical conditions and soil erosion characteristics in this region, the following aspects need be studied further to meet the multiobjective demands of land degradation control, grain production increases, and sustainable development in the tableland-gully region of the CLP.

(1) The comprehensive management of soil erosion in the tableland-gully region of the CLP is focused on preventing the gully head from moving forward and reducing the surface runoff. Under the guidance of "controlling gully \& protecting tableland", soil erosion control has achieved remarkable results, but research on the effect of soil erosion and control mechanisms of ecological remediation is scarce. It is necessary to study the effects of ecological remediation on soil erosion and spatial differentiation and further clarify the changes and scale effects of soil erosion under different ecological remediation models, such as slope erosion, gully erosion effects, and control mechanisms. 
(2) The two-element agricultural model of grain and fruit has gradually become an important eco-restoration model on the loess tableland, and research on the sustainability of this model needs to be strengthened. Scholars should consider the safety of regional water and soil resources and the multifunctional requirements of ecosystems, construct an index system and quantitative evaluation model of the ecosystem carrying capacity, and clarify the relationship between the regional soil and water resources and the ecosystem carrying capacity. The comprehensive management mode should be chosen according to the local conditions to serve superior agricultural industries, such as the apple industry, and maintain a virtuous ecosystem cycle.

(3) Taking small watersheds as the unit for the comprehensive control of soil and water loss, the influence mechanisms of different remediation models on the structure and function of regional ecosystems can be revealed by considering spatial-temporal multiscale coupling. According to the quantitative relationship between the ecological remediation mode and function, the mechanism and approach of optimizing the ecological remediation structure and upgrading the function can be explored to effectively implement the "controlling gully \& protecting tableland" strategy, and can promote the steady development of vegetation construction, soil, and water conservation in the tableland-gully region, including the CLP.

\section{Conclusions}

Overall, the study based on the SCI and CNKI databases showed that the quantity of SCI literatures has increased rapidly since 2007, with an average annual growth rate of $21.4 \%$. The quantity of CNKI literatures in the last decade accounted for $62 \%$ of the past 30 years. The research hotspots in the SCI literature were mainly related to loess geology in the early stage, while the CNKI literature focused on agricultural production. However, the two databases tended to be consistent in the latter stage, including the management of sloping farmland, the improvement of agricultural productivity, the control of soil erosion, and the two-element agricultural model of grain and fruit and ecological construction. In addition, the highly cited papers mainly focused on soil reservoir reconstruction, farmland water use efficiency improvement, land use adjustment, soil erosion control measure exploration, and vegetation restoration. However, the effects of soil erosion control under different ecological remediation models, and the mechanism of ecosystem maintenance and regulation approaches that are based on the sustainable utilization of soil and water resources must be further explored.

Author Contributions: Study design and Methodology, W.L.; Data curation, G.L. and Y.W.; Writing-original draft, Y.W.; Writing-review editing, Y.W., W.Y. and G.G.; Funding acquisition, W.L. and G.G.

Funding: This study was supported by the National Key Research and Development Program of China (2016YFC0501602) and the National Nature Science Foundation of China (41571036).

Conflicts of Interest: The authors declare no conflict of interest.

\section{References}

1. Cerdà, A.; Flanagan, D.C.; Bissonnais, Y.L.; Boardman, J. Soil erosion and agriculture. Soil Tillage Res. 2009, 106, 107-108. [CrossRef]

2. Zhang, T.L.; Wang, X.X. Development and orientation of research work on soil degradation. J. Nat. Resour. 2000, 15, 280-284. (In Chinese)

3. Zheng, F.L. Effect of vegetation changes on soil erosion on the Loess Plateau. Pedosphere 2006, 16, 420-427. [CrossRef]

4. Keesstra, S.; Mol, G.; de Leeuw, J.; Okx, J.; de Cleen, M.; Visser, S. Soil-Related Sustainable Development Goals: Four Concepts to Make Land Degradation Neutrality and Restoration Work. Land 2018, 7, 133. [CrossRef]

5. Masselink, R.; Temme, A.J.A.M.; Giménez, R.; Casalí, J.; Keesstra, S.D. Assessing hillslope-channel connectivity in an agricultural catchment using rare-earth oxide tracers and random forests models. Cuad. Investig. Geogr. 2017, 43, 17-39. [CrossRef] 
6. Keesstra, S.; Nunes, J.P.; Saco, P.; Parsons, T.; Poeppl, R.; Masselink, R.; Cerdà, A. The way forward: Can connectivity be useful to design better measuring and modelling schemes for water and sediment dynamics? Sci. Total Environ. 2018, 644, 1557-1572. [CrossRef]

7. Rodrigo-Comino, J. Five decades of soil erosion research in "terroir." The State-of-the-Art. Earth-Sci. Rev. 2018, 179, 436-447. [CrossRef]

8. Rodrigo-Comino, J.; Keesstra, S.; Cerdà, A. Soil erosion as an environmental concern in Vineyards. The case study of Celler del Roure, eastern Spain, by means of rainfall simulation experiments. Beverages 2018, 4, 31. [CrossRef]

9. Trimble, S.W.; Crosson, P.U.S. Soil Erosion Rates: Myth and Reality. Science 2000, 289, 248-250. [CrossRef]

10. Nicu, I. Is Overgrazing Really Influencing Soil Erosion? Water 2018, 8, 1077. [CrossRef]

11. Beyene, S.T. Rangeland degradation in a semi-arid communal savannah of swaziland: Long-term DIP-Tank use effects on woody plant structure, cover and their indigenous use in three soil types. Land Degrad. Dev. 2015, 26, 311-323. [CrossRef]

12. Stefanos, S.; Dimitrios, S. Effects of climate change on soil erosion in a mountainous Mediterranean catchment (center Pindus, Greece). Water 2018, 10, 1469. [CrossRef]

13. Lopez-Vicente, M.; Navas, A. Predicting soil erosion with RUSLE in mediterranean agricultural systems at catchment scale. Soil Sci. 2009, 5, 272-282. [CrossRef]

14. Feng, Q.; Zhao, W.; Qiu, Y.; Zhao, M.; Zhong, L. Spatial Heterogeneity of Soil Moisture and the Scale Variability of Its Influencing Factors: A Case Study in the Loess Plateau of China. Water 2013, 5, 1226-1242. [CrossRef]

15. Fu, B.J.; Yu, L.; Lu, Y.H.; He, C.S.; Zeng, Y.; Wu, B.F. Assessing the soil erosion control service of ecosystems change in the Loess Plateau of China. Ecol. Complex. 2011, 8, 284-293. [CrossRef]

16. Shi, H.; Shao, M.A. Soil and water loss from the Loess Plateau in China. J. Arid. Environ. 2000, 45, 9-20. [CrossRef]

17. Wang, X.; Zhao, X.L.; Zhang, Z.X.; Yi, L.; Zuo, L.J.; Wen, Q.K.; Liu, F.; Xu, J.Y.; Hu, S.G.; Liu, B. Assessment of soil erosion change and its relationships with land use/cover change in China from the end of the 1980s to 2010. Catena 2016, 137, 256-268. [CrossRef]

18. Wang, W.Z.; Jiao, J.Y.; Ma, L.M.; Mu, X.M. Variation of sediment yield in different soil erosion areas and its control standard on the Loess Plateau. Bull. Soil Water Conserv. 2012, 5, 1-7.

19. Jiang, D.S.; Liu, Z.; Fan, X.K. Research on regionalization plan of comprehensive control and development model in severe soil erosion area of Loess Plateau. Res. Soil Water Conserv. 1994, 1, 11-22, 28. (In Chinese)

20. Peng, H.; Jia, Y.; Tague, C.; Slaughter, P. An eco-hydrological model-based assessment of the impacts of soil and water conservation management in the Jinghe River basin, China. Water 2015, 11, 6301-6320. [CrossRef]

21. Wu, G.L.; Zhang, Z.N.; Wang, D.; Shi, Z.H.; Zhu, Y.J. Interactions of soil water content heterogeneity and species diversity patterns in semi-arid steppes on the Loess Plateau of China. J. Hydrol. 2014, 519, 1362-1367. [CrossRef]

22. Wang, D.; Liu, Y.; Shang, Z.H.; Tian, F.P.; Wu, G.L.; Chang, X.F.; Warrington, D. Effects of grassland conversion from cropland on soil respiration on the semi-arid Loess Plateau, China. Clean-Soil Air Water 2015, 7, 1052-1057. [CrossRef]

23. Liu, Y.; Zhao, W.; Zhang, X.; Fang, X. Soil water storage changes within deep profiles under introduced shrubs during the growing season: Evidence from semiarid Loess Plateau, China. Water 2016, 8, 475. [CrossRef]

24. Nederhof, A.J. Bibliometric monitoring of research performance in the social sciences and the humanities: A Review. Scientometrics 2006, 66, 81-100. [CrossRef]

25. Gao, J.K. Application of bibliometrics methods in scientific evaluation. Knowl. Libr. Inf. Sci. 2005, 2, 14-17. (In Chinese)

26. Li, Z.Q.; H, H. Analysis of actuality of water-saving irrigation technique in China-Based on the literature metrology of scientific knowledge map. Water Sav. Irrig. 2015, 8, 104-109.

27. Liu, X.; Zhang, L.; Hong, S. Global biodiversity research during 1900-2009: A bibliometric analysis. Biodivers. Conserv. 2011, 20, 807-826. [CrossRef]

28. Yevide, A.S.I.; Wu, B.; Khan, A.S.; Zeng, Y.; Liu, J. Bibliometric analysis of ecosystem monitoring-related research in Africa: Implications for ecological stewardship and scientific collaboration. Int. J. Sustain. Dev. World Ecol. 2016, 23, 412-422. [CrossRef] 
29. Chen, C.M. CiteSpace II: Detecting and visualizing emerging trends and transient patterns in scientific literature. J. Am. Soc. Inf. Sci. Technol. 2006, 57, 359-377. [CrossRef]

30. Chen, Y.; Chen, C.M.; Liu, Z.Y.; Hu, Z.G.; Wang, X.W. The methodology function of citesoace mapping knowledge domains. Stud. Sci. Sci. 2015, 33, 242-253.

31. Taşkın, Z.; Aydinoglu, A.U. Collaborative interdisciplinary astrobiology research: A bibliometric study of the NASA Astrobiology Institute. Scientometrics 2015, 103, 1003-1022. [CrossRef]

32. Li, J.; Chen, C.M. CiteSpace Scientific text Mining and Visualization; Capital University of Economics/Business Press: Beijing, China, 2016; ISBN 9787563824649.

33. Han, J.M.; Lu, H.Y.; Wu, N.Q.; Guo, Z.T. Magnetic susceptibility of modern soils in China and its use for paleoclimate reconstructions. Stud. Geophys. Geod. 1996, 40, 262-275.

34. Maher, B.A.; Thompson, R. Paleorainfall Reconstructions from Pedogenic Magnetic Susceptibility Variations in the Chinese Loess and Paleosols. Quat. Res. 1995, 44, 383-391. [CrossRef]

35. Liu, T.S.; Guo, Z.T.; Wu, N.Q.; Lu, H.Y. Prehistoric vegetation on the Loess Plateau: Steppe or forest? J. Southeast Asian Earth Sci. 1996, 13, 341-346.

36. Li, Y.S.; Zhang, X.Z.; Guo, M.H. The field experiments on the field-research of crops to water and fertility in the south of the Loess Plateau. Acta Pedol. Sin. 1990, 5, 1-7.

37. Li, Y.S. Regularities and improving ways of crop productivity in dryland farming. Chin. J. Soil Sci. 1990, 5, 4-7.

38. Jiang, D.S.; Fan, X.K.; Li, X.H.; Zhao, H.L. Study on horizonal and vertical regulation of soil anti-scourability in area wuth serious soil erosion on Loess Plateau. J. Soil Water Conserv. 1995, 2, 1-8.

39. Liu, B.Y.; Nearing, M.A.; Risse, L.M. Slope gradient effects on soil loss for steep slopes. Trans. ASAE 1994, 37, 1835-1840. [CrossRef]

40. Zheng, F.L.; Tang, K.L.; Zhou, P.H. Study on factors affecting rill erosion on cultivated slope land. Acta Pedol. Sin. 1989, 2, 109-116. (In Chinese)

41. Fu, B.J.; Gulinck, H. Land evaluation in an area of severe erosion: The loess plateau of China. Land Degrad. Dev. 1994, 5, 33-40. [CrossRef]

42. Tang, K.L.; Zhang, Z.Z.; Kong, X.L.; Cha, X.; Shi, R.Y. A study of soil loss and soil degradation in the Loess Plateau. Bull. Soil Water Conserv. 1987, 6, 12-18.

43. Li, H.F. On the theory and methods for the comprehensive harness of small watershed. J. Soil Water Conserv. 1989, 3, 21-25.

44. Tang, K.L. Discussion on comprehensive control of small watershed in water and wind crisscrossed erosion region on the Loess Plateau. Res. Soil Water Conserv. 1996, 4, 46-55.

45. Zhang, X.C.; Liu, W.Z. Simulating potential response of hydrology, soil erosion, and crop productivity to climate change in Changwu tableland region on the Loess Plateau of China. Agric. For. Meteorol. 2005, 131, 127-142. [CrossRef]

46. Stocking, M.; Lu, Y. Integrating biophysical and socio-economic aspects of soil conservation on the Loess Plateau, China. Part I. Design and calibration of a model. Land Degrad. Dev. 2000, 11, 125-139. [CrossRef]

47. Zhou, Z.C.; Shangguan, Z.P.; Zhao, D.L. Modeling vegetation coverage and soil erosion in the Loess Plateau Area of China. Ecol. Model. 2006, 198, 263-268. [CrossRef]

48. Kang, S.Z.; Zhang, L.; Liang, Y.L.; Hu, X.T.; Cai, H.J.; Gu, B.J. Effects of limited irrigation on yield and water use efficiency of winter wheat in the Loess Plateau of China. Agric. Water Manag. 2002, 55, 203-216. [CrossRef]

49. Huang, Y.L.; Chen, L.D.; Fu, B.J.; Huang, Z.L.; Gong, J. The wheat yields and water-use efficiency in the Loess Plateau: Straw mulch and irrigation effects. Agric. Water Manag. 2005, 72, 209-222. [CrossRef]

50. Xu, X.Z.; Zhang, H.W.; Zhang, O.Y. Development of check-dam systems in gullies on the Loess Plateau, China. Environ. Sci. Policy. 2004, 7, 79-86.

51. Fan, T.L.; Stewart, B.; Yong, W.; Luo, J.J.; Zhou, G.Y. Long-term fertilization effects on grain yield, water-use efficiency and soil fertility in the dryland of Loess Plateau in China. Agric. Ecosyst. Environ. 2005, 106, 313-329. [CrossRef]

52. Huang, M.B.; Shao, M.A.; Zhang, L.; Li, Y.S. Water use efficiency and sustainability of different long-term crop rotation systems in the Loess Plateau of China. Soil Tillage Res. 2003, 72, 95-104. [CrossRef]

53. Huang, M.B.; Kang, S.Z.; Li, Y.S. A comparison of hydrological behaviors of forest and grassland watersheds in gully region of the Loess Plateau. J. Nat. Resour. 1999, 14, 226-231. 
54. Liu, G.B. Soil conservation and sustainable agriculture on the Loess Plateau: Challenges and prospects. AMBIO-A J. Hum. Environ. 1999, 8, 663-668.

55. Wang, L.X. Concepts and principles of integrated small watershed management. Soil Water Conserv. China 2006, 2, 16-17.

56. Yu, X.X.; Bi, H.X.; Zhu, J.Z.; Wu, B. Soil and water conservation by forest vegetation in loess area. Chin. J. Plant Ecol. 1997, 5, 433-440.

57. Jiang, D.S.; Fan, X.K.; Huang, G.J. Experiment of the evaluation on benefits of soil and water conservation measures for slope land. J. Soil Water Conserv. 1992, 2, 1-10.

58. Liu, B.Y.; Zhang, K.L.; Jiao, J.Y. Soil erodibility and its use in soil erosion prediction model. J. Nat. Resour. 1999, 4, 345-350.

59. Yang, Q.K.; Li, R. Review of quantitative assessment on soil erosion in China. Bull. Soil Water Conserv. 1998, 18, 14-19. (In Chinese)

60. Wu, F.Q.; Liu, H.B.; Sun, B.S.; Zhou, Z.L.; Wang, J. Energy flow of agro-fruit ecosystem in the Loess Plateau of Shaanxi Province. Chin. J. Eco-Agric. 2008, 16, 1005-1010. [CrossRef]

61. Guo, S.L.; Che, S.G.; Liang, W.; Yang, Q.K. SOC spatial distribution at small Wangdonggou watershed in gully region of the Loess Plateau. Atca Ecol. Sin. 2010, 30, 52-59. (In Chinese)

62. Li, Z.; Liu, W.Z.; Yang, Q.K.; Liang, W.; Li, S.J.; Gan, Z.T.; Wang, B.; Wang, R. Land use/land cover changes and their ecological effect in small watershed on gully region of the Loess Plateau. Chin. J. Appl. Ecol. 2007, 18, 1299-1304. (In Chinese)

63. Peng, S.H.; Tang, C. Blending the analytic hierarchy process and fuzzy logical system in scenic beauty assessment of check dams in streams. Water 2015, 12, 6983-6998. [CrossRef]

64. Cao, S.X.; Chen, L.; Yu, X.X. Impact of China's Grain for Green Project on the landscape of vulnerable arid and semi-arid agricultural regions: A case study in northern Shaanxi Province. J. Appl. Ecol. 2009, 46, 536-543. [CrossRef]

65. Feng, Q.; Guo, X.; Zhao, W.; Qiu, Y.; Zhang, X. A Comparative analysis of runoff and soil loss characteristics between "extreme precipitation year" and "normal precipitation year" at the plot scale: A case study in the Loess Plateau in China. Water 2015, 7, 3343-3366. [CrossRef]

66. Li, T.; Gao, Y. Runoff and sediment yield variations in response to precipitation changes: A case study of Xichuan watershed in the Loess Plateau, China. Water 2015, 10, 5638-5656. [CrossRef]

67. Wang, Y.Q.; Shao, M.A.; Zhu, Y.J.; Liu, Z.P. Impacts of land use and plant characteristics on dried soil layers in different climatic regions on the Loess Plateau of China. Agric. For. Meteorol. 2011, 151, 437-448. [CrossRef]

68. Wang, D.; Wu, G.L.; Zhu, Y.J.; Shi, Z.H. Grazing exclusion effects on above-and below-ground C and N pools of typical grassland on the Loess Plateau. Catena 2014, 123, 113-120. [CrossRef]

69. Li, Y.S.; Huang, M.B. Pasture yield and soil water depletion of continuous growing alfalfa in the Loess Plateau of China. Agric. Ecosyst. Environ. 2008, 124, 24-32. [CrossRef]

70. Chen, H.Q.; Hou, R.X.; Gong, Y.S.; Li, H.W.; Fan, M.S.; Kuzyakov, Y. Effects of 11 years of conservation tillage on soil organic matter fractions in wheat monoculture in Loess Plateau of China. Soil Tillage Res. 2009, 106, 85-94. [CrossRef]

71. Wu, G.L.; Liu, Y.; Fang, N.F.; Deng, L.; Shi, Z.H. Soil physical properties response to grassland conversion from cropland on the semi-arid area. Ecohydrology 2016, 8, 1471-1479. [CrossRef]

72. Wang, Y.Q.; Zhang, X.C.; Huang, C.Q. Spatial variability of soil total nitrogen and soil total phosphorus under different land uses in a small watershed on the Loess Plateau, China. Geoderma 2009, 150, 141-149. [CrossRef]

73. Fang, X.; Xue, Z.J.; Li, B.C.; An, S.S. Soil organic carbon distribution in relation to land use and its storage in a small watershed of the Loess Plateau, China. Catena 2012, 88, 6-13. [CrossRef]

74. Li, Y.; Wu, Q.X.; Zhu, X.M.; Tian, J.Y. Studies on the intensification of soil anti-scourability by plant roots in the loess plateau. J. Soil Water Conserv. 1990, 4, 1-5. (In Chinese)

75. Zhu, X.M. "Saving Soil Water Reservoir" is a key issue for integrated control of ecological environment and sustainable development on Loess Plateau. J. Soil Water Conserv. 2000, 14, 1-6. (In Chinese)

76. Zhu, X.M. Rebuild soil reservoir is a rational approach for soil and water conservation on the Loess Plateau. Bull. Chin. Acad. Sci. 2006, 21, 320-324. (In Chinese)

77. Shan, L.; Xu, M. Water-saving agriculture and its physio-ecological bases. Chin. J. Appl. Ecol. 1991, 2, 70-76. (In Chinese) 
78. Kang, S.Z.; Shi, W.J.; Zhang, J.H. An improved water-use efficiency for maize grown under regulated deficit irrigation. Field Crop. Res. 2000, 67, 207-214. [CrossRef]

79. Shan, L. Plant water use efficiency and agricultural water use in semi-arid areas. Plant Physiol. Commun. 1994, 1, 61-66. (In Chinese)

80. Zhao, G.J.; Mu, X.M.; Wen, Z.M.; Wang, F.; Gao, P. Soil erosion, conservation, and eco-environment changes in the Loess Plateau of China. Land Degrad. Dev. 2013, 24, 499-510.

81. Liu, B.Z.; Li, G.L.; Wu, F.Q.; Zhao, X.G. The regular patterns of the loess of soil nutrients on southern Loess Plateau. J. Soil Water Conserv. 1995, 9, 77-86. (In Chinese)

82. Li, Y.S. Effects of forest on water circle on the Loess Plateau. J. Nat. Resour. 2001, 16, 427-432. (In Chinese)

83. Zhang, X.P.; Zhang, L.; Zhao, J.; Rustomji, P.; Hairsine, P. Responses of streamflow to changes in climate and land use/cover in the Loess Plateau, China. Water Resour. Res. 2008, 44, 2183-2188. [CrossRef]

84. Li, Y.S. Productivity dynamic of alfalfa and its effects on water eco-environment. Acta Pedol. Sin. 2002, 39, 404-411. (In Chinese)

85. Chen, H.S.; Shao, M.A.; Li, Y.Y. Soil desiccation in the Loess Plateau of China. Geoderma 2008, 143, 91-100. [CrossRef]

86. Wang, L.X.; Zhang, Z.Q. Impact of forest vegetation on watershed runoff in dryland areas. J. Nat. Resour. 2001, 16, 439-444. (In Chinese)

87. Huang, M.B.; Yang, X.Y.; Li, Y.S. Effect of apple base on regional water cycle in Weibei upland of the Loess Plateau. Acta Geogr. Sin. 2001, 56, 7-13. (In Chinese)

88. Sun, C.Z.; Huang, B.L.; Chen, H.B.; Liu, Z.W.; Wen, Z.M. Interaction between soil water conditions and different kinds of artificial plant cover in the Loess Plateau. J. Beijing For. Univ. 1998, 3, 7-14. (In Chinese)

89. Yang, W.Z. Soil water resources and afforestation in Loess Plateau. J. Nat. Resour. 2001, 16, 433-438. (In Chinese)

(C) 2018 by the authors. Licensee MDPI, Basel, Switzerland. This article is an open access article distributed under the terms and conditions of the Creative Commons Attribution (CC BY) license (http:/ / creativecommons.org/licenses/by/4.0/). 